\title{
Air drying technique for cytogenetic studies in freshwater planarians (Platyhelminthes)
}

\author{
CECILIA B. MARGARÍA and FERNANDO N. DULOUT *
}

Facultad de Ciencias Naturales y Museo, Universidad Nacional de La Plata. Paseo del Bosque s/n, $1900 \mathrm{La}$ Plata; * Centro de Investigaciones en Genětica Básica y Aplicada (CIGEBA), Facultad de Ciencias Veterinarias, Universidad Nacional de La Plata. 60 y 118, CC 296, 1900 La Plata, Argentina.

Cytogenetic studies in seawater or land planarians have been generally performed by means of the squash technique (BALL and DE VRIES 1983; Curini-Galletti et al., 1985, 1989a, b; Martens et al. 1989a, b; OKi et al. 1991; Puccineli and Curini-Galletrti 1987; Tamura et al. 1991). However, the quality of chromosome preparations obtained by squashing in terms of spreading and detritus background is not as good as that obtained by using the air drying technique in other taxa. In addition, few information is available about citogenetic techniques for freshwater invertebrates.

The air drying technique (RothFelds and Siminovitch 1958) was proposed for cytogenetic analysis of mammalian bone marrow cells and it included previous tissue disgregation. For nearly forty years the technique became widely used, with several modifications, for cytogenetic studies even in plant cells.

This paper describes the modifications made in the technique for the analysis of planarians chromosomes.

Specimens were collected in Arroyo Zapata, a small water course in the Province of Buenos Aires, Argentina during the spring season.

Whole living animals - three or four each time - were washed in physiological solution $\mathrm{NaCl} 0.6 \%$ (GABE 1968) and then transferred to a clock glass with a solution of colchicine $(0.3 \%)$ dissolved in Gabe's solution. The animals were cut with a scalpel under a magnifying glass until complete disgregation. The disgregated tissues were transferred to a centrifuge tube. After resuspending with a Pasteur pipette the cells were left into the tube for three hours. The material was centrifuged at 800 r.p.m. for $5 \mathrm{~min}$ and the supernatant was replaced with hypotonic solution ( $\mathrm{KCl} 0.075 \mathrm{M}$ ). After incubation for $30 \mathrm{~min}$ at $20^{\circ} \mathrm{C}$ the hypotonic solution was replaced by fixative (methanol-acetic acid 3:1) and the tubes were stored at $4^{\circ} \mathrm{C}$ overnight. After 

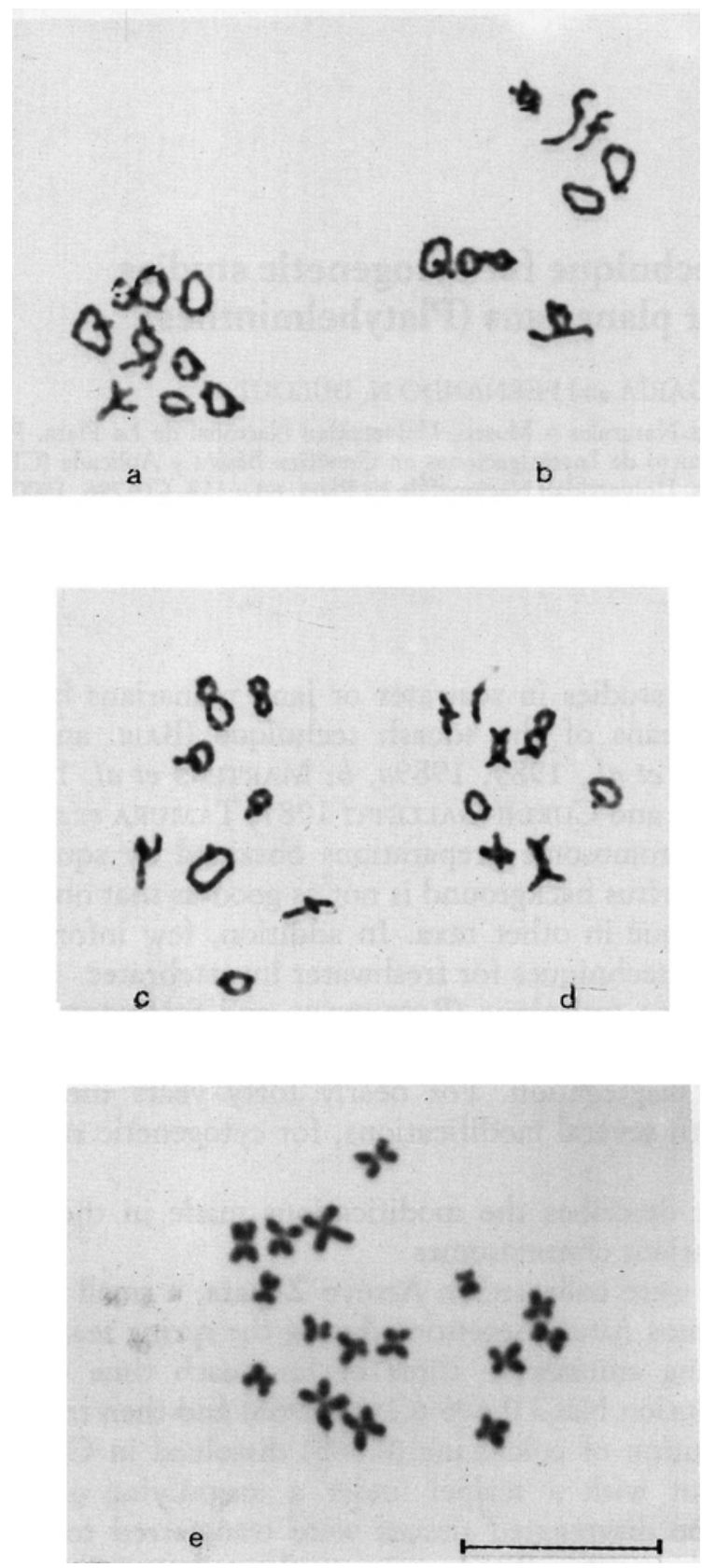

Fig. 1. - Micrographs of different plates: a. b. c. d. diacinesis - metaphase I; e. Mitotic metaphase. The bar indicates $10 \mu \mathrm{m}$. 
one or two changes of fixative, cromosome preparations were made by droping the cell suspension on frozen slides. Preparations were stained with Giemsa $5 \%$ for 2 minutes.

Using the whole specimens good plates of mitotic and meiotic cells in the same slide were obtained. As it can be seen in Fig. 1, chromosomes are well spread and the slide has not any detritus or cytoplasmic background. Consequently, morphological analysis of the chromosome complement is very easy and fast. On the other hand, the technique is very simple and reliable and can be used in other invertebrates.

\section{REFERENCES}

BALL I.R. and DE VRIES E.J., 1983. - Karyological studies on land planarians (Tricladida, Terricola). Caryologia, 36: 195-202.

Curini-Galletti M., Martens P.M. and Puccinelli I., 1985. - Karyological observations on Monocelididae (Turbellaria, Proseriata): karyometrical analysis of four species pertaining to the subfamily Minoninae. Caryologia, 38: 67-75.

Curnini-GalletTT M. and Puccinelur I., 1989a - Karyometric and morphological analysis of two sympatric marine species of the Gyratrix hermaphroditus complex (Platybelminthes: Kalyptorbynchia) occurring at Roscoff (Brittany, France). Hydrobiologia, 173: 63-68.

Curini-Galletti M., Puccinelui I. and Martens P.M., 19896. - Karyometrical analysis of 10 species of the subfamily Monocelidinae (Proseriata, Platybelminthes) with remarks on the karyological evolution of the Monocelididae. Genetica, 78: 169-178;

Gabe M., 1968. - Techniques bistologiques. 1051 pp. Masson et Cie, Paris.

Martens P.M., Curini-Galletti M.C. and Puccinelli I., 1989a. - On the morphology and karyology of the genus Archilopsis (Meixner) (Platybelminthes, Proseriata). Hydrobiologia, 175: 237-256.

Martens P.M., Curint-Galletti M.C. and van Oostveldt M.C., $1989 b$ - Polyploidy in Proseriata (Platybelminthes) and its phylogenetical implications. Evolution, 43: 900-907.

OKi I., TAMura S., OGRen R. and Kawakatsu M., 1991. - Karyology of four land-planarian species of the genus Bipalium from Japan. Hydrobiologia, 227: 163-167.

Puccinelli I. and Curini-Gallettri M.C., 1987. - Chromosomal evolution and speciation in marine populations of Gyratrix hermapibroditus sensu lato (Platybelminthes: Kalyptorbynchia) and in other species of the Gyratricinae. Trans. Am. Microsc. Soc., 106: 311-320.

RoTHFELDS K.N. and SIMINOVITCH L., 1958. - An air drying technique for flattering chromosomes in mammalian cells growth in vitro. Stain Technol., 33: 73-77.

TAMURA S., OKI I and KAwAKATSU M., 1991. - Karyological and taxonomic studies of Dugesia japonica from the Southwest islands of Japan-II. Hydrobiologia, 227: 157-162. 